\title{
Family 4.0: Alteration Family Life In The Industrial Revolution 4.0
}

\author{
Sri Wahyuandayani, Siti Mariah, Anggri Sekar Sari \\ \{buswandayani@gmail.com¹, siti.mariah@ustjogja.ac.id², anggri_sekar@yahoo.com³ \\ Pendidikan Kesejahteraan Keluarga, Universitas Sarjanawiyata Tamansiswa, Yogyakarta Indonesia ${ }^{1}$,
}

\begin{abstract}
The main purpose of this article is to discuss changes in family life in the era of the industrial revolution 4.0 which are reviewed from the impact of using gadgets and the internet. Based on a review of meta-analysis studies on several research results, experiences of parents and children, and interviews with experts. The results showed that families with formal working parents benefited from the era of industrial revolution 4.0 in terms of communication without limits of space and time, the ease of obtaining basic family needs (food, clothing, cosmetics, accessories, household appliances, etc.) that could be obtained quickly. But the other side has a negative impact on industry 4.0 developments, especially families with children under 10 years, some cases show that gadget addiction has experienced communication delays, physical and mental disorders. It is suggested that show how this scientific research can be used for applied purposes.
\end{abstract}

Keywords: family life, industry 4.0, internet of things, gadget.

\section{Introduction}

In the era of industrial revolution 4.0 there has been a transformation in family institutions which is one of the main domains of social structure[1]. The use of information communication technology has become endemic, which has changed the pattern of family interaction.[2] Patterns in the family also influence other social processes. The fact is that family life has changed in the last generation, despite the emergence of technology. The size of the house has increased by 50 percent, which means that family members can retreat to the corner of their own home, so it is unlikely that parents and children will see each other. Because everyone is so busy with work, school and extracurricular activities, there is less time for families to spend time together.[3][4]

Efforts to support and strengthen families vulnerable to crisis. The form of social interaction in the family that is influenced by the use of gadgets can change the function of the family itself. Where behavior between parents, or parents to children in their care is not intact, where communication, closeness, support, and involvement of parents are no longer felt or carried out to the maximum.[5]

Parents who use smartphone technology provide many uses, such as being able to communicate smoothly with other people, get information quickly, can help parents to get information related to their work. But many disadvantages are getting parents who do not 
really understand how to use smartphone technology, such as social inequalities between parents and society and families, disrupt health, disrupt the family economy and reduce the religious value that exists in the parents themselves.[6]

Technology can have many benefits for children when used properly and under supervision, but may only use it as their children's caregivers because they have no time or interest to play with their children. I really understand the argument of using it as an educational tool, and even that rare use is only to get a break so you can do some of the things needed around the house. The problem comes with abuse and assumes that an environment full of technology will prepare children with the ability to use new technology and develop in the future.[7] [8]. The use of ICT gadgets affects the interactions and relationships between parents, children and partners that they cannot do with their responsibilities according to their social roles. Increasing feuds among family members have weakened families and marriage institutions because of the rapid use of ICT.

None of the effects of popular culture and technology on children's relationships are more real than in families. Both of these influences have contributed to the growing division between the traditional roles played by children and their parents, while at the same time, blurring the same lines between parents and children. Because of the lack of technological acumen on the part of many parents, they have no authority, at least in the eyes of their children, to regulate their use. Because of parents' anxieties or concerns about using technology, they may not want to impose themselves on the technological life of their children. Because of their children's superiority and lack of respect for parental authority on this issue, children may not listen to their parents' efforts to guide or limit their use of technology.

have given children freedom in their communication with friends and others. In the previous generation, if children wanted to connect with a friend, they had to ask permission from their parents. Thus, parents have the opportunity to monitor and act as gatekeepers for the social lives of their children.[9] Parents, in turn, see it as losing the connection to their children and the inability to maintain reasonable supervision, for the overall safety and health, the lives of their children. At the same time, there are parents who feel they don't have to bother entertaining their children, giving them more time for themselves[10].

The study in the study explained the benefits and negatives of the industrial revolution 4.0 era on the order of family life which included patterns of interaction, parenting patterns, and economics. The source of the study is screening from various data sources (interviews, observations, documents) and research articles.

\section{Research Methods}

This study uses the Meta-Analysis design. Simple meta-analysis can be interpreted as an analysis of analysis. As a research, meta-analysis is a study of a number of research results in similar problems. The instrument in this study uses Human Instrument.

Meta-analysis introduces a series of quantitative analysis techniques that enable the synthesis of various research results. [10] The analysis in the meta-analysis is based on the availability of artifact information from each study result. After the focus of the research becomes clear, simple research instruments will be developed, which are expected to be able to complete data and compare data that has been found before. Data collection techniques will use documentation techniques. The population in this study are all written documents on the 
issue of industry 4.0 influence on family life. The written documents include books, journal articles, and research reports. The research sample was taken using purposive sampling technique. This is because the data or information to be obtained from the sample is determined based on its suitability with the theme of this research. Data analysis used is quantitative data analysis with percentage and qualitative data analysis for data from the results of narrative studies of the studies encountered.

\section{Result And Discution}

\subsection{Research Results}

The studies on the impact of industry 4.0 on family life obtained were as much as research. The studies were obtained from various sources, namely: the influence of technology on family life both positively and negatively from the eyes of parents, children, and adolescents[11][1][12][13][14][15][16][17][18][19][20][21][22][1][9][7][23][24][3][24][25][2 $2][26][25]$. In general, the data is obtained by downloading from the internet.

\subsection{Meta analysis of research objectives}

Industry 4.0 impact studies on families use several research designs, namely: survey, phenomenology, then the design used as shown in the following table 6 :

Table 1. Research design

\begin{tabular}{lcc}
\hline \multicolumn{1}{c}{ Research Design } & frekuensi & \% \\
\hline Survei & 19 & 79.2 \\
phenomenology & 5 & 20.8 \\
R \& D & - & - \\
Total & 24 & 100 \\
\hline
\end{tabular}

\subsection{Meta analisis based on population}

The population/sample used in industry studies 4.0 or the subjects of the research are children, adolescents, parents of three levels of school. Based on a study of 20 studies, the population/sample can be seen in the following table:

Table 2. Research subject

\begin{tabular}{lcc}
\hline \multicolumn{1}{c}{ Research Subjek } & frekuensi & \% \\
\hline Child & 2 & 8.4 \\
Teenager & 5 & 20.8 \\
Parents & 13 & 54.2 \\
Parent and Child & 4 & 16.6 \\
Total & 24 & 100 \\
\hline
\end{tabular}

\subsection{Meta-analysis based on methods/data collection techniques}

Methods/techniques of data collection used in research on industry 4.0 consist of Test methods, Observations, Questionnaires, and interviews. Based on a study of 20 studies on the 
impact of gadgets on family life, the methods/techniques of data collection used can be seen in table 3 below:

Table 3. Data collection

\begin{tabular}{lcc}
\hline \multicolumn{1}{c}{ Data collection } & frekuensi & \% \\
\hline Interviews and observation & 5 & 20.8 \\
Qoesioner & 17 & 70.8 \\
Mix methods & 2 & 8.4 \\
Jumlah & 24 & 100 \\
\hline
\end{tabular}

\subsection{The data analysis technique}

The data analysis technique used in studies on industry 4.0 consists of:, then the data analysis technique used can be seen in Table 4 below:

Table 4. Data analysis technique

\begin{tabular}{|c|c|c|}
\hline $\begin{array}{c}\text { Data analysis } \\
\text { technique }\end{array}$ & frekuensi & $\%$ \\
\hline Uji-t & 3 & 12.4 \\
\hline Descriptive qualitative & 5 & 20.8 \\
\hline Descriptive quantitative & 17 & 70.8 \\
\hline Jumlah & 24 & 100 \\
\hline
\end{tabular}

From a review of the results of the study, in general there are some data that the industrial revolution era 4.0 is characterized by digitalization, internet of things, and gadget, smartphone devices, in influencing family life, both children, adolescents, and parents. Industry 4.0 has a positive impact on parents in terms of interaction and communication, economy, recreation. Positive impact on adolescents in terms of learning achievement because of the ease of getting knowledge, friendship and creativity. But it can be fatal if there is no supervision and control from the parents. The results showed several phenomena of addiction to gadgets which resulted in mental disorders. Impact of industry 4.0 for children tends to be more negative, the impact on health, verbal, physical and mental communication disorders.

\section{Conclution}

The industrial revolution 4.0, which is characterized by the digital era and the internet of things on various communication devices, is very influential on family life, both positive and negative in terms of economy, communication, creativity, but can negatively affect children if not under the supervision of parents. Negative tendencies can be overcome through several strategies for parents in educating children wisely.

Acknowledgment. I want to thank some people whose contribution is the key to resolving it this job. First, I want to thank the researchers who participated in this study, this paper is not possible without your cooperation. First, I want to express my gratitude to Bayu Rahmat Setiadi, who has supported me in-depth feedback and wise criticism during the process. In addition, I want to thank Heri Nurdianto, for editing and translation and motivation. Finally, thanks to colleagues for keeping me calm during this process, and providing continuous 
feedback, editing grammar, and becoming a soundboard. I can't do this without all the help of these people.

\section{References}

[1] F. Walsh, "A family resilience framework: Innovative practice applications," Fam. Relat., vol. 51, no. 2, pp. 130-137, 2002.

[2] G. Esping-Andersen, Families in the 21st Century. 2016.

[3] M. Arnot, "Families Are Changing," J. Community Dev. Soc., vol. 6, no. 2, pp. 36-44, 1975.

[4] E. A. Alampay, L. P. Alampay, and K. S. Raza, "ICTs and Connectedness in Families of Filipino Migrant Workers ICTs and Connectedness in Families of Filipino Migrant Workers," Alleviating Digit. poverty with ICT Innov. Emerg. Econ. Will ICT rights make a Differ. IDIA 2012 Conf. Proc., no. SEPTEMBER, pp. 23-43, 2012.

[5] J. Sandlin, "Family Business Adaptation to Disruptive Technology," Fam. Bus. Adapt. to Disruptive Technol., no. 15, 2017.

[6] E. Scotland, "Engaging with Parents," no. 21, 2010.

[7] E. N. Patrikakou, "Parent Involvement, Technology , and Media : Now What?," vol. 26, no. 2, pp. 9-24.

[8] E. Wartella, V. Rideout, A. R. Lauicella, and S. L. Connell, "Parenting in the age of digital technology: A national survey," no. June, p. 32, 2014.

[9] S. Livingstone, G. Mascheroni, and M. Dreier, "How parents of young children manage digital devices at home," no. September, 2015.

[10] M. I. of N. M. T. on S. I. in the H. Corcoran, "The Impact of New Media Technologies on Social Interaction in the Household," Electron. Cult. Soc. Chang., no. April, p. 48, 2012.

[11] W. Fleeson et al., "pengaruh media sosial terhadap keharmonisan kel," J. Pers. Soc. Psychol., vol. 1, no. 1, pp. 1188-1197, 2017.

[12] I. Lestari, A. W. Riana, and B. M. Taftarzani, "34 Pengaruh gadget pada interaksi sosial dalam keluarga,” Pros. Ks Ris. Pkm, vol. 2, no. 2, pp. 147-300, 2015.

[13] Nurmalasari, "PENGARUH PENGGUNAAN GADGET TERHADAP TINGKAT PRESTASI that are easy to carry anywhere for," Ilmu Pengetah. Dan Teknol. Komput., vol. 3, no. 2, pp. 111-118, 2018.

[14] A. Efendi, P. I. Astuti, and N. T. Rahayu, "Analisi Pengaruh Penggunaan Media Baru Terhadap Pola Interaksi Sosial Anak di Kabupaten Sukoharjo,” J. Penelit. Hum., vol. 18, no. 1, pp. 12-24, 2017.

[15] "Pengaruh_Media_Sosial_Terhadap_Perkemban.”.

[16] M. Ngafifi, "Advances in Technology and Patterns of Human Life in Socio-Cultural Perspective," Kemajuan Teknol. dan Pola Hidup Mns., vol. 2, no. 1, pp. 33-47, 2014.

[17] P. A. Chusna, "Pengaruh Media Gadget Pada Perkembangan Karakter Anak," Din. Penelit., vol. 17, no. 2, pp. 315-330, 2017.

[18] Juniver, V. Mokalu, N. N. Mewengkang, and J. P. M. Tangkudung, "Dampak Teknologi Smartphone Terhadap Perilaku Orang Tua di Desa Touure Kecamatan Tompaso," Acta Diurna, vol. 5, no. 1, pp. 1-9, 2016.

[19] S. M, "The Impact of using Gadgets on Children," J. Depress. Anxiety, vol. 07, no. 01, pp. 1-3, 2017.

[20] “THE_IMPACT_OF_GADGETS_IN_LEARNING_AMONG (1).”.

[21] N. Kurniasih, "Internet Addiction, Lifestyle or Mental Disorder? A Phenomenological Study on Social Media Addiction in Indonesia," KnE Soc. Sci., vol. 2, no. 4, p. 135, 2017.

[22] Z. X. Chena and C. C. Chena, "The Intention of Using Smart Device Messages as Parent-teacher Communication from the View of Parents," Procedia Manuf., vol. 3, no. Ahfe, pp. 5617-5623, 2015.

[23] H. Saleem, Z. Fatima, S. A. Hadi, A. Nasir, and M. Riaz, "Family in Globalization Era: a Study on Ict," Explor. J. Soc. Sci., vol. 1, no. 2, pp. 2411-13229, 2006. 
[24] K. R. \& K. S. Veerle Van Rompaey, "Children's Influence on Internet Access at Home: Adoption and use in the family context," J. Information, Commun. Soc., vol. Volume 5, no. 2, pp. 189-206, 2010.

[25] S. W. \& J. D. essie Rudi, Jodi Dworkin, "Parents' use of information and communications technologies for family communication: differences by age of children," Information, Commun. Soc., vol. 18, no. 1, pp. 78-93, 2015.

[26] V. S. Katz, M. B. Moran, and K. Ognyanova, "Contextualizing connectivity: how internet connection type and parental factors influence technology use among lower-income children," Inf. Commun. Soc., vol. 0, no. 0, pp. 1-23, 2017. 